\title{
DIALEKTIKA ANTARA KEMASLAHATAN DAN TEKS DALAM SYARIAH
}

\author{
Moch. Zainul Arifin \\ Institut Agama Islam Negeri Sunan Ampel, Jl. A Yani I 17 Surabaya | \\ zainularifin23l@gmail.com
}

\begin{abstract}
This article discusses the dialetics between the benefit and the text in shariah. The purpose of shariah is to reach the benefit of mankind. It means that the entire texts and their laws serve to realize the benefit and to prevent damage, and should be based on the principle of beneficial understanding, the application of which within the scope of the benefit, and the text as a standard of benefit. The benefit is an important spirit behind shariah. Because of that, the understanding of the text in a legal reasoning process needs a solid foundation. Basically, the emergence of contradiction between benefit and text is nothing other than the two things: first, errors in understanding and concluding the benefit; second, errors in understanding and actualizing the text. Actualization of the benefit of the text is a branch and an expansion of the welfare interpretation of the text. This actualization plays an important role in eliminating the contradiction between the text and welfare. Therefore, it is necessary to actualize the enlightened benefit by seeing, considering, and excluding the conditions that lead to a damage.
\end{abstract}

Keywords: Benefit, text, shariah.

Abstrak: Artikel ini membahas tentang dialetika antara kemaslahatan dan teks dalam syariah. Syariah tidak memiliki tujuan lain selain kemaslahatan umat manusia, begitu pula bahwa seluruh teks dan hukum-hukumnya berfungsi merealisasikan kemaslahatan dan mencegah kerusakan, dan hukum-hukumnya harus berlandaskan pada prinsip memahami teks sebagai kemaslahatan, aplikasi praktisnya dalam lingkup kemaslahatan, dan teks sebagai stándar kemaslahatan. Kemaslahatan adalah ruh penting di balik syariah, karena itu dalam memahami teks dalam berijtihad perlu dasar pijakan yang kokoh. Munculnya kontradiksi kemaslahatan dan teks, pada dasarnya tidak lain dari dua hal: pertama, kesalahan dalam memahami dan menyimpulkan 
kemaslahatan, kedua, kesalahan dalam memahami dan mengaktualisasikan teks. Aktualisasi kemaslahatan (al-tatbiq al-maslahi) atas teks adalah cabang dan perluasan dari tafsir kemaslahatan (al-tafsir al-maslahi) atas teks. Aktualisasi ini berperan dalam menghilangkan kondisi yang dipandang menimbulkan kontradiksi antara teks dan kemaslahatan. Oleh karena itu, perlu aktualisasi kemaslahatan yang tercerahkan dengan melihat, mempertimbangkan, dan mengecualikan kondisi yang mengarah pada kerusakan, sehingga tercipta kemaslahatan lain yang lebih jelas.

Kata Kunci: Kemaslahatan, teks, syariah.

\section{Pendahuluan}

Terdapat banyak faktor mengapa proses ijtihad di kalangan ulama belum menghasilkan produk yang memuaskan. Salah satu di antaranya adalah adanya anggapan bahwa pintu ijtihad sudah tertutup bagi umat Islam dewasa ini. Guna menyelesaikan segala persoalan yang dihadapi umat, pendapat semacam ini menganjurkan agar mencukupkan diri pada produk-produk ijtihad ulama pertengahan. Padahal esensi dan bobot persoalan yang dihadapi ummat Islam abad pertengahan jelas berbeda dari substansi persoalan sekarang ini. Di saat zaman semakin kompleks seiring dengan pesatnya perkembangan ilmu pengetahuan dan teknologi, dibutuhkan sebuah upaya penyegaran baru terhadap peran ijtihad agar keberadaannya benar-benar menjadi berkah bagi umat Islam sekarang ini.

Dalam konteks inilah, tulisan ini hendak merespon isu perlunya merevitalisasi peran ijtihad dalam menghasilkan produkproduk hukum yang sejalan dengan kebutuhan umat Islam. Kertas kerja ini berargumen bahwa untuk memperoleh hasil ijtihad yang relevan dengan tuntutan atau kebutuhan zaman, perangkat ijitihad perlu dilengkapi dengan khasanah keilmuan di luar disiplin hukum Islam. 


\section{Argumen Normatif Ijtihad}

Salah satu hadis yang menjadi rujukan dalam melihat pentingnya ijtihad adalah hadis Nabi Muhammad sebagaimana diriwayatkan dalam Ŝhihayn (dua kitab hadis utama, yang diriwayatkan oleh Imam Bukhari dan Imam Muslim) berikut ini: "Jika seorang hakim memutuskan hukum dengan berijtihad dan kemudian benar, maka ia mendapat dua pahala, dan jika memutuskan hukum dengan berijtihad dan kemudian salah, maka ia mendapat satu pahala."1

Namun demikian, justifikasi hadis ini rupanya belum cukup kuat untuk mendorong dibukanya kembali pintu ijtihad dan menegaskan urgensinya. Padahal hadis ini sangat jelas memberikan afirmasi tentang pentingnya ijtihad. Dalam konteks inilah, sungguh mengherankan jika masih ada sejumlah pihak yang mempropagandakan tertutupnya pintu ijtihad, padahal hadis Nabi ini secara eksplisit menyatakan bahwa jika seorang mujtahid yang salah saja masih diberi pahala oleh Allah, apalagi jika dia benar dalam melakukan istinbat hukum. ${ }^{2}$

Perlu ditegaskan kembali bahwa para Nabi juga berijtihad, dan ijtihad mereka terkadang salah. Beberapa pakar teologi Islam (usuliyyin) mempermasalahkan adanya ijtihad yang dilakukan Nabi Muhammad, karena ia adalah pembawa wahyu; bagaimana mungkin ia diperbolehkan untuk berijtihad dalam mengubah sesuatu yang buruk menjadi yang baik dan melakukan ijtihad spekulatif (al-dan), padahal segala yang berasal dari Nabi adalah keyakinan dan kebenaran? Dari sini sejumlah usuliyyin menolak adanya ijtihad pada diri Nabi Muhammad. ${ }^{3}$

Bentuk kesalahan ijtihad yang dilakukan para Nabi banyak dijelaskan dalam al-Qur'an, termasuk pada diri Nabi Muhammad dan beberapa Nabi sebelumnya. Hal ini sebagai dorongan bagi

\footnotetext{
' Abu al-Ma'ali 'Abd al-Malik al-Juwayni, Kitab al-litihad min Kitab al-Talkhis, (Damaskus: Dar alQalam, 1987), 26-32.

${ }^{2}$ Ibid., 28.

${ }^{3}$ Jalal al-Din 'Abd al-Rahman al-Suyuti, Ikhtilaf al-Madhahib, ed. 'Abd al-Qayyum Muhammad alBastawi, (Kairo: Dar al-I'tisam, 1404H).
}

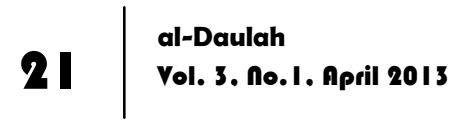


para ulama untuk tetap mendayagunakan peran ijtihad dalam memecahkan berbagai persoalan keummatan. Kondisi ini sama sekali tidak mengurangi derajat para Nabi serta tidak menodai kemaksuman (suci dari dosa) mereka. Kemaksuman para Nabi yang pertama dan utama adalah dalam dakwah mereka, dan kemudian mereka maksum dari perbuatan maksiat kepada Allah. Sedangkan kesalahan ijtihad bukanlah dianggap sebagai kesalahan, aib, dan kekurangan. Oleh karena itu, mengapa kita tidak mendayagunakan ijtihad? Bedanya, wahyu selalu mengingatkan atas segala kesalahan yang dilakukan oleh Nabi dalam ijtihadnya serta meluruskan hukum dan implementasinya. Dengan demikian tidak akan muncul persepsi kesalahan akan validitas dakwah, legalitas, dan ajaran-ajaran Nabi. ${ }^{4}$

Dengan demikian dapat kita katakan bahwa Rasulullah sangat menganjurkan ijtihad seperti apa yang ia lakukan dan contohkan, sebagaimana mendorong ijtihad dengan sabdanya. Wahyu yang terlambat atau terlalu singkat dan bersifat umum terkadang memaksa Nabi untuk berijtihad, dan para sahabat ikut serta dalam proses ijtihad ini dengan bimbingan Nabi. Peristiwa seperti ini banyak terjadi dan direkam dalam al-Qur'an dan sunnah. Dalam kaitan ini, perlu diungkap pengertian, indikasi dan makna ijtihad secara luas, bahkan perlu dikembangkan seluas mungkin, karena pembatasan dalam mencari indikasi-indikasi teks dan pereduksian dalam proses aktualisasinya merupakan bentuk ketidakpedulian atas sesuatu yang menjadi kewajiban.

\section{Ijtihad: antara Kebebasan dan Tanggung Jawab}

Ketika Islam mendorong umatnya untuk melakukan ijtihad dalam menyelesaikan berbagai persoalan keagamaan bukan berarti mereka bebas mutlak untuk melakukannya sekehendak hati, dan tidak berarti setiap mujtahid bebas mengatakan apa saja sesuai dengan diri dan pikirannya. Tetapi ijtihad adalah ilmu dan

${ }^{4}$ Ibid., 38.

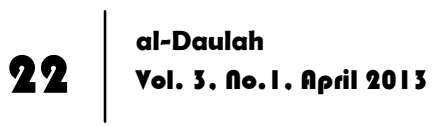


tradisi yang memerlukan pembuktian dan penalaran. Ijtihad adalah amanat dan merupakan amanat yang paling tinggi derajatnya.

Hal tersebut dikarenakan di saat kelompok pro ijtihad berbenturan dengan kelompok anti ijtihad yang merupakan pendukung gerakan taklid dan jumud, muncul suara dari kelompok lain yang menyerukan ijtihad tanpa batas dan aturan, atau interpretasi tanpa landasan dan kontrol. Kecenderungan ini dinamakan dengan gerakan transformasi (al-taghyir), dan orientasi gerakan ini sangat mirip dengan aliran batiniyah dalam sejarah Islam, dimana interpretasi teks berseberangan dengan kaidah tata bahasa dan apa yang diketahui masyarakat umum. Bahasa yang merupakan sarana mengungkapkan pikiran, dianggap sebagai sesuatu yang berbentuk simbol, dengan demikian mereka bebas menginterpretasikan teks dan merealisasikan tujuan yang diinginkan. ${ }^{5}$

Saat ini tidak begitu urgen memfokuskan kajian pada gerakan pemikiran ini serta memperbincangkan pokok pemikiran dan ijtihad mereka. Tetapi cukup dengan mendiskusikan pokok pemikiran mereka dan landasan-landasannya untuk mengetahui sampai dimana kadar keilmuan dan rasionalitasnya, termasuk apakah pemikiran ini dapat ditransformasikan dan dijadikan rujukan. Mereka mengatakan bahwa:

- Tidak ada seorang pun yang memiliki otoritas tunggal untuk menafsirkan agama.

- Tidak ada seorang pun yang berhak mengatasnamakan agama Islam dan syariah.

- Tidak ada seorang pun yang berhak mengaku sebagai pemilik kebenaran.

- Islam tidak mengenal sistem kependetaan dan kerahiban.

- Setiap individu berhak memahami agama dan menafsirkannya, dan itu tergantung kepada diri dan jiwanya.

${ }^{5}$ Ali Jum'ah, Qadiyyah Tajdid, Usul al-Fiqh, (Beirut: Dar al-Hidayah, |4|4/I993), 46.

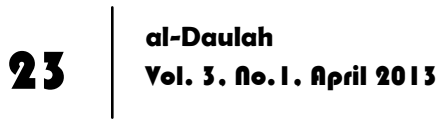


- Penafsiran agama harus mengikuti perkembangan zaman dan selalu up to date, sehingga tidak terbelenggu hanya pada masa awal hijriah atau masa awal Islam.

Pada hakekatnya tafsir, interpretasi ( $\left.t a^{\prime} w i l\right)$, dan ijtihad dalam agama lebih membutuhkan syarat-syarat, kecakapan, dan keahlian tertentu daripada bidang keilmuan lainnya, termasuk sikap teliti dan berhati-hati. Saat ini sering didapatkan beberapa orang nekat yang mengkritisi agama dan mengemukakan pandangan dan ideide kontroversial, memotong dan memilah-milah persoalan yang kemudian ditakwilkan dan diinterpretasikan sekehendak hatinya mengikuti alur kehendaknya, menganggap dirinya pemikir bebas, mujtahid pembaharu, dan pelopor pembaharuan, padahal ia tidak memiliki keahlian sama sekali tentang substansi persoalan, tidak banyak pengetahuan yang diketahuinya kecuali sebagian kecil yang bersifat parsial, dan mengemukakan pandangan yang tidak valid legalitasnya.

Bagaimanapun juga, kajian dan studi keislaman yang dilakukan para peneliti dan pemikir dari berbagai macam disiplin keilmuan dan keahlian, seperti dokter, insinyur, wartawan, filsuf, sejarawan dan politisi tidaklah dilarang. Tetapi mereka diharapkan untuk berhati-hati, rendah hati, dan mengerti akan kapasitas intelektual mereka terhadap bidang ini. ${ }^{6}$ Akan lebih baik jika mereka meminta pertimbangan dan saran dari mereka yang ahli dan pakar dalam bidang ini, sebagaimana yang lain meminta pertimbangan dan kritikan kepada mereka dengan bidang keahliannya. Dimanapun dan kapanpun manusia berijtihad, dan ingin pandangan, ide, dan perkataannya didengar dan diterima, maka ia harus menjadi orang yang ahli, pakar, dan spesialis dalam bidangnya, karena jika tidak maka ia menjerumuskan dirinya dalam kepicikan dan kehancuran. Pandangan seperti ini bersifat dogmatis-aksiomatik dan banyak dibicarakan dalam al-Qur'an, bahkan dianjurkan dan diperingatkan agar manusia tidak

${ }^{6}$ Lihat, Subhi Mahmasani, Falsafah al-Tashri' fi al-Islam, (Beirut: Dar al'Ilm li-Malayin, 196I), 2124. 
terjerumus, sebagaimana disebutkan dalam al-Qur'an (QS. 17:36; QS. 7:33; QS. 16:43; QS. 4:83).

Profesi sebagai pemikir dan peniliti patut diapresiasi, sebab setiap bertambah ilmu pengetahuan dan pengalaman mereka, maka semakin cermat, teliti, dan mendalam pengetahuan dan penalaran mereka. Apalagi bagi mereka yang konsentrasi studinya adalah syariah dan intens dengan kajian-kajian filsafat dan ekonomi, atau memiliki banyak pengalaman sosial, politik, dan administrasi, maka tidak diragukan lagi kapasitas intelektual dan keilmuan seperti ini akan lebih luas dan mendalam pemahaman dan ijtihadnya terhadap syariah. Oleh karena itu jika ada orang yang pakar bidang tertentu, kemudian mengkritik bidang lain seperti bidang agama tanpa pengetahuan sedikit pun dan tidak pada aturan metodologi, maka pasti tidak akan diterima. ${ }^{7}$

Tidak adanya keahlian terjadi, misalnya, pada pemikir dan penulis terkenal seperti Dr. Muhammad Talbi ketika menulis: "diceritakan secara tawatur (periwayatan akurat oleh banyak orang dari banyak orang yang lain) gaya bahasa memuji bahwa Imam Malik berpendapat boleh membunuh sepertiga demi kebaikan dua pertiga." ${ }^{8}$ Ia tidak memperhatikan dan membatasi arti kata tawatur, padahal tawatur bermakna riwayat yang mendekati kepastian karena banyak perawinya mustahil terjerumus kebohongan. Kemudian tanpa ragu-ragu menyatakan: "jika benar apa yang diriwayatkan", maka bagaimana ia tidak yakin dengan sesuatu yang diriwayatkan secara tawatur?

Sedangkan mereka yang ahli dan pakar dalam bidangnya, memiliki pandangan lain atas riwayat yang menyesatkan ini. Seorang faqih dari Tunisia mengatakan bahwa ungkapan di atas yang dinisbahkan kepada Imam Malik ternyata tidak memiliki dasar dan rantai silsilah (sanad) yang jelas. Kemudian ia menyatakan bahwa ungkapan "boleh membunuh sepertiga demi

\footnotetext{
${ }^{7}$ Ibid., 26.

${ }^{8}$ Muhammad Talbi, lyaullah, Afkar Jadidah fi 'Alaqah al-Muslim bi Nafsihi wa bi al-Akharin, (Dar Siras li al-Nasr, 1992), 82.
} 
kebaikan duapertiga" adalah paham aliran Al-Hajjaj, karena dia orang yang pertama menyatakan demikian dan selanjutnya disebarluaskan oleh para pengikutnya. Paham ini menghalalkan pertumpahan darah sesama muslim demi menjaga stabilitas kekuasaan, sebagaimana yang dilakukan sendiri oleh al-Hajjaj ibn Yusuf. ${ }^{9}$

Dalam tulisannya, Dr. Talbi juga menegaskan bahwa "seorang muslim memiliki kebebasan dan harus tunduk kepada teks, karena jika menolak teks akan bertentangan dengan keyakinan, dan ideologinya". ${ }^{10}$ Akan tetapi keharusan ini seakan hilang tanpa makna ketika ia mengatakan "setiap dari kita berinteraksi dengan teks dengan cara masing-masing"11 ataupun pernyataannya: "Jika kita tidak terbebas dari bayang-bayang tradisi pemikiran salaf, maka seharusnya mereka memberi kebebasan bagi orang-orang sesudahnya untuk berinteraksi dengan teks." 12

Apakah ini bukan jalan singkat menuju apa yang disebut DR. Talbi dalam tulisannya dengan istilah "manipulasi teks" (al-talaub bi al-nas)? ${ }^{13}$ Sungguh mengherankan ia selalu menolak konstruksi pemikiran salaf dan berusaha memarginalkannya, namun ketika menentang pendapat orang-orang yang menafsirkan ayat: "Kemudian jika kamu takut tidak dapat berlaku adil, maka (kawinilah) seorang saja" (QS. An-Nisa.4;3), yang bermakna pengharaman poligami dan pembatalannya, ia langsung merujuk pada pemahaman salaf dan realitas kongkrit penerapanya pada abadabad yang lalu dengan mengatakan: "Kaum muslimin sepanjang sejarahnya tidak mengartikan ayat ini sebagai larangan, apakah masuk akal jika seluruh kaum muslimin menghalalkan sesuatu dan diterapkan hingga sekarang kemudian terbukti bahwa ayat

\footnotetext{
9 Muhammad al-Syazili al-Naifur, "Man bahasa lahu 'an al-Maslahah al-Mursalah", dalam Multaqa al-Imam Muhammad ibn Arafah, (Mansyurat al-Hayat al-Tunisiyah, 1977), 288.

10 Muhammad Talbi, lyaullah, Afkar, 73

"Ibid., 74.

${ }^{12} \mathrm{lbid} ., 137$.

$13 \mathrm{lbid}$.
} 
tersebut bermakna larangan? Sungguh ini tidak masuk akal. Hal ini terlepas dari pandangan subyektif seseorang bahwa seorang suami dengan seorang istri adalah sistem keluarga yang terbaik, dan ini cukup sebagai alasan menolak adanya "manipulasi teks". ${ }^{14}$

Slogan yang selalu di serukan Dr. Talbi bahwa "teks adalah suci (al-nas muqaddas) dan interpretasi adalah bebas" (al-ta'wil huff) sangat kontroversial bagi para pemerhati ilmu ini. Yang pasti, asumsi ini tidak akan diterima oleh kalangan mereka, jika tidak ada aturan batasan, dan ketentuan ilmiah dalam interpretasi bebas. Slogan "teks adalah suci dan interpretasi adalah bebas" telah memunculkan pandangan bahwa al-Qur'an tidak melarang khamr (minuman keras) secara tegas, karena hanya menyuruh untuk menghindarinya saja, dan bukan pelarangan. Slogan ini juga memunculkan pandangan bahwa hukum potong tangan dan hukum cambuk bagi pezina adalah sunnah, boleh dan tidak wajib. Dengan slogan ini pula muncul pandangan yang membolehkan perkawinan perempuan muslimah dengen laki-laki ahl al-kitab. ${ }^{15}$

Dalam konteks ini pula seorang insinyur bernama Muhammad Shahrur kebablasan dalam menerapkan kebebasan interpretasi dan ijtihad dengan mengatakan: "ijtihad tidak mungkin dilakukan jika tidak membongkar kerangka ini -yakni aturan-aturan dasar yang berlaku- dan kembali melakukan pembacaan wahyu dengan landasan pengetahuan kekinian, serta bersandar pada konsep baru bagi fikih Islam."16

Jika Dr. Talbi menafsirkan ayat al-Qur'an sekehendak hatinya dengan penafsiran yang tidak dikatakan oleh siapapun sebelumnya, sedangkan sejarah Islam merekam bentuk penafsiran seperti ini sebagai penyimpangan dan tidak masuk akal, serta menjadi bagian dari "manipulasi teks". Maka insinyur Shahrur, setelah mengingkari adanya naskh dalam hukum syariah,

\footnotetext{
${ }^{14}$ Ibid.

15 Yusuf Qaradawi, Ijtihad al-Mu'asir baina al-Indibat wa al-Infirat, (Dar al-Tauzi" wa al_Nasyr alIslamiyah, |994-|4|4), 54-57.

${ }^{16}$ Muhammad Syahrur, Dirâsat Islamiyah Muâsirah fi ad-Daulah wa al-Mujtama, (Damaskus: AlAhali li al-Taba ah wa al-Nasyr wa al-Tauzi', 1994), 218.
} 
mengatakan: "tidak terlalu penting bagi saya apakah hal ini telah dikatakan orang lain sebelum saya atau tidak, apakah sesuai dengan ijma' (konsensus) ulama atau tidak, dan apakah mengikuti ijma' mayoritas ulama atau tidak." 17

\section{Teks dan Kemaslahatan}

Salah satu problem kekinian yang ramai dibicarakan dalam konteks syariah yang menyangkut hal-hal yang pokok (uŝul) dan cabang (furu') adalah persoalan 'teks dan kemaslahatan' (al-nas\} wa wa al-maslahah). Barangkali persoalan ini akan menyemarakkan perdebatan intelektual dan pemikiran Islam pada masa modern ini sebagaimana persoalan lainnya yang telah ramai dibicarakan seperti masalah akal dan naql (wahyu), khalq al-Qur'an (kemakhlukan al-Qur'an), sifat-sifat Tuhan, dan persoalan lainnya yang menggemparkan sejarah pemikiran Islam. Problem "teks dan kemaslahatan" hampir mirip dengan problem "akal dan wahyu", bahkan ia adalah dua wajah yang sama, atau bagian dari bagian lainnya.

Walaupun demikian mayoritas penulis dan pemikir modernis menyerukan untuk memprioritaskan kemaslahatan atas teks, karena teks dianggap melayani kemaslahatan dan mengarah kepada tercapainya kemaslahatan. Al-maslahah (kemaslahatan) adalah titik tolak, dasar utama, dan tujuan diturunkannya syariah dan teks. Sedangkan para pakar yurisprudensi Islam aliran salaf mengingkari dan menolak pandangan ini.

Taerdapat dua persoalan yang berbeda; pertama, persoalanpersoalan dan masalah yang terdapat dalam teks, dan hukumnya ditetapkan secara terperinci dan jelas. Kedua, persoalan-persoalan dan masalah baru yang tidak dijelaskan oleh teks secara khusus, terbatas, ataupun langsung. Tidak diragukan lagi bahwa perdebatan yang terjadi saat ini sangat berkaitan dengan bidang pertama, sedangkan pada bidang kedua, perselisihan jarang terjadi 
dan kalaupun ada hanya seputar landasan teoritis. Oleh karena itu, yang menjadi persoalan adalah bidang kedua saja dengan tetap terfokus pada bidang pertama, dan khususnya pada beberapa permasalahannya.

\section{Syariah adalah Kemaslahatan, dan Kemaslahatan adalah Syariah}

Jika syariah adalah ke mas\}lah\}ahatan (al-Shari'ah maslahah), maka pandangan ini diakui oleh seluruh kaum muslimin dan diterima oleh mayoritas ulama dalam setiap masa, tempat, dan madzhab, kecuali madzhab literalis (zâhiriyyah), dan itu tidak berpengaruh secara kuantitas ataupun kualitas.

Ungkapan dan perkataan para ulama yang menjelaskan hal ini adalah:

- al-Shari'ah jấat al-jalb al-masalih wa dar'u al-mafâsid (syariah datang membawa kemaslahatan dan mencegah mafsadat).

- al-Shari'ah naf'u wa daf'u (Syariah membawa manfaat dan menolak kerugian).

- al-Shari'ah jâ'at jalb al-masalih wa taksiruha wa dar'u al-mafasid wa taqliluha (Shari'ah datang membawa kemaslahatan dan memperbanyaknya serta mencegah mafsadat dan menguranginya).

- al-Shari'ah innama wudi'at li masâlih al-'ibad fi al-ajil wa al-ajl ma'an (syariah di tetapkan untuk kemaslahatan seluruh manusia pada masa kini dan masa depan).

- al-Syariah mabnâha wa asâsuhâ 'ala al-hikam wa masalih al-'ibad wa hiya 'adl kulluhâ, wa rahmah kulluhâ, wa masalih kulluha (syariah berdasarkan pada hikmah dan kemaslahatan manusia, yaitu keadilan universal, rahmat universal, dan kemaslahatan universal).

- Haythumâ kânat al-maslahah fasamma shar' Allah, wa haythumâ kâna shar' Allah fasamma al-maslahah (diamana terdapat kemaslahatan maka disitulah syariah Tuhan, begitupula diamana terdapat syariah Tuhan maka disitu terdapat kemaslahatan. 
Bahkan Najm al-Din al-Tufi yang terkenal dengan teori kemungkinan kontradiksi antara teks dan maslahah mengatakan: "secara garis besar, tidak ada ayat pada kitab suci al-Qur'an yang tidak mengandung manfaat dan kemaslahatan". ${ }^{18}$ Kemudian disebutkan pula bahwa kedudukan sunnah sebagaimana kedudukan al-Qur'an dengan mengatakan: "karena sunnah adalah bayân (penjelasan) atas al-Qur'an, dan telah kami terangkan bahwa semua ayat mengandung kemaslahatan, maka al-bayan (penjelasan) mengikuti al-mubayyan (apa yang dijelaskan)" ${ }^{19}$

Mengenai kemaslahatan adalah syariah, maka banyak ide dan gagasan yang dikemukakan para pakar yurisprudensi Islam dengan menciptakan prinsip-prinsip dan kaidah-kaidah yang pada intinya adalah kemaslahatan. Salah satu yang terkenal adalah prinsip "al-maslahah al-mursalah" yang dianggap sebagai landasan dan sumber penetapan hukum syariah bagi mayoritas ulama, dan hanya Maliki saja yang berlainan terhadap prinsip ini. Al-Qarafi mengatakan: "Konsep al-maslahah tidak diakui oleh kalangan selain kami, namun dalam permasalahan furu' engkau akan temui bahwa mereka juga mempergunakan konsep al-maslahah secara umum. Mereka tidak memaksa diri untuk memunculkan alasan spekulatif dengan cara membandingkan ketika terjadi perbedaan atau persamaan, akan tetapi lebih mendasarkan pada konteks, dan ini adalah kemaslahatan. ${ }^{20}$

Selain dari al-maslahah al-mursalah (kemaslahatan umum), ada prinsip-prinsip lain yang substansinya adalah memelihara kemaslahatan dan dijadikan landasan hukum, antara lain:

- Istihsan, yang bentuk dan penerapannya banyak digunakan untuk memelihara kemaslahatan, sebagaimana yang dikatakan Ibnu Rushd: "makna yang sering digunakan dari istihsan

\footnotetext{
${ }^{18}$ Abdul Wahab Khalaf, Masadir at-Tashri' al-Islamiy fi ma la Nas Fihi, (Kuwait: Dar al-Qalam, I 392 H / 1972 M, Cet. III), I I6. Dalam buku ini terdapat teks pembahasan at-Tufi yang dinukil secara lengkap.

${ }^{19} \mathrm{lbid}$.

${ }^{20}$ Al-Din Ahmad bin Idris al-Qarafi. Al-Zakhirah, (Bayrut: Dar al-Gharb al-Islami, I 994), 152.
} 
adalah peduli pada kemaslahatan dan keadilan..$^{21}$ Oleh karena itu dapat saja dikatakan bahwa definisi istihsan adalah meninggalkan qiyas (analogi) dan mengambil sesuatu yang lebih baik bagi manusia.

- Sadd al-dhdhara'i', yang tujuan akhirnya adalah mencegah kerusakan (mafsadat). Kemaslahatan muncul dari prinsip ini ketika ia melarang sesuatu yang dibolehkan teks, meskipun hal ini bertentangan dengan teks, namun tujuannya adalah demi tercapainya kemaslahatan serta penjagaan atasnya

- 'urf (adat istiadat) dan istidlal (penalaran induksi), keduanya bertanggungjawab untuk memelihara kemaslahatan dan sebagai landasan hukum.

- Begitupula beberapa kaidah fikih yang menjadi landasan dalam pembentukan syariah yang penuh maslahat dan penerapannya, antara lain :

- al-Asl fi al-manâfi' al-hall wa fi al-mudâr al man'u (asal segala yang bermanfaat adalah boleh, dan segala yang mudarat adalah dilarang).

- La darar wa lâ dirar (jangan menimbulkan kemudaratan dan jangan menjadi korban kemudaratan)

- al-darar yuzâl (bahaya harus ditinggalkan)

- al-darar la yuzâlu bi mithlih (bahaya tidak boleh dihilangkan dengan bahaya yang sama)

- Yahtamil al-darar al-khâs li daf'i al-darar al-'âmm (memilih bahaya yang jangkauannya terlokalisir untuk mencegah bahaya yang lebih meluas).

- Al-darar al-ashadd bi al-darar al-akhaf (bahaya yang lebih besar dihilangkan dengan bahaya yang lebih ringan).

- Al-tasarruf 'ala al-ra'iyyah manût bi al-maslahah (mengurusi urusan rakyat harus mengikuti kemaslahatan).

Sangat jelas terlihat seperti yang telah saya sebutkan dengan dasar-dasar dan kaidah-kaidah fikih - bagaimana pentingnya 
kedudukan al-maslahah adalah syariah, dan hal itu merupakan pengertian dari ungkapan: "dimana terdapat kemaslahatan maka disitulah syariah Tuhan". Oleh karena itu Imam Al-Ghazali mengatakan: "terkadang kami menjadikan hukum yang lain sebagai argumen atasnya". ${ }^{22}$

\section{Pengertian Kemaslahatan}

Untuk mendapatkan pemahaman yang benar dan tepat akan pengertian maslahat, maka harus dilihat dari berbagai sisi dan sudut pandang. Pengertian maslahat secara sederhana dan universal, yaitu maslahat adalah segala sesuatu yang mengandung kebaikan dan manfaat bagi sekelompok manusia dan juga individu. Selanjutnya dilihat dari sisi lain akan ditemukan wajah lain dari maslahat yaitu mafsadat. Tidak mungkin memelihara kemaslahatan dan kemudian melupakan eksesnya yaitu mafsadat. Oleh karena itu dalam mencapai kemaslahatan harus dihindarkan segala kerusakan baik sebelum dan sesudahnya, atau yang mengikuti dan menyertainya.

Kemudian jika dilihat dari sudut waktu yang panjang, didapatkan bahwa kemaslahatan karena perkembangan zaman dapat berubah menjadi sesuatu yang merusak sebaliknya. Begitupula suatu kemaslahatan yang dianggap remeh pada kurun waktu yang pendek, namun menjadi penting dalam jangka panjang atau sebaliknya. Sesuatu hal yang menjadi maslahat bagi generasi tertentu terkadang malah bahaya bagi generasi selanjutnya. Dan yang paling berbahaya adalah apa yang dianggap sebagai kemaslahatan di dunia ini ternyata membawa kerusakan di akhirat, atau sebaliknya. Oleh karena itu apa yang dianggap sebagai kemaslahatan pada masanya dan menjadi kerusakan pada masa selanjutnya atau masa depan, maka pada hakekatnya tidak dianggap sebagai kemaslahatan.

${ }^{22}$ Imam al-Ghozali, Al-Mankhul Min Ta'liqot al-Ushul, (Damaskus: Darul Fikr, 1980), Cet: Il, 355.

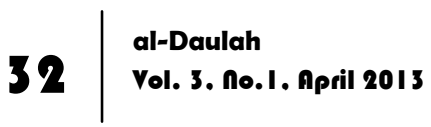


Salah satu contoh menarik dalam konteks ini adalah persoalan tanah rampasan pada masa Khalifah 'Umar bin Khattab. Para prajurit dan pejuang dari kalangan sahabat meminta agar tanah tersebut dibagikan kepada mereka. Akan tetapi beberapa sahabat lain menentang pembagian tersebut agar manfaat dan kegunaannya dapat dirasakan oleh generasi selanjutnya dari para pejuang dan kaum muslimin, akhirnya pendapat ini yang disetujui Umar dan didukung oleh para pemuka sahabat dari kalangan Muhajirin dan ansar. Ide menentang pendapat pertama dikemukakan oleh sahabat Ali ibn Abi Thalib dan Mu'az ibn Jabal dengan mengatakan kepada Umar: "jika anda membagi tanah tersebut maka sangat berguna bagi mereka, akan tetapi kemudian akan lepas dan berpindah tangan kepada khalayak umum dari laki-laki atau perempuan. Kemudian suatu hari nanti muncul generasi yang membela Islam dan mereka tidak menemukan apaapa, maka pertimbangkanlah yang terbaik bagi mereka dan generasi sesudahnya”. Abu 'Ubaidah berkata: "kemudian Umar lebih memihak kepada pendapat $\mathrm{Mu}^{\prime} \mathrm{az}$ dan pendapat ini dikemukakan olehnya dari Ali ibn Abi Thalib. ${ }^{23}$ Tidak diragukan lagi bahwa pembagian tanah untuk para tentara adalah demi kepentingan dan kemaslahatan mereka, akan tetapi proyeksi jangka panjang dan masa depan memiliki perspektif lain, dan ini yang dipilih oleh para sahabat yang memiliki pandangan kemaslahatan ke depan.

\section{Interaksi Kemaslahatan dengan Teks}

Syariah tidak memiliki tujuan lain selain kemaslahatan umat manusia, begitu pula bahwa seluruh teks dan hukum-hukumnya berfungsi merealisasikan kemaslahatan dan mencegah kerusakan, dan hukum-hukumnya harus berlandaskan pada prinsip memahami teks sebagai kemaslahatan, aplikasi praktisnya dalam lingkup kemaslahatan, dan teks sebagai stándar kemaslahatan.

\footnotetext{
${ }^{23}$ Abu Ubaidah, Al-Amwal li Abi 'Ubaidah, (Kairo: al-Maktabah at-Tijariyah al-Kubra, t.t), 59-60.
}

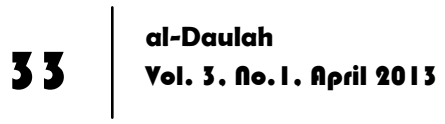


Semua teks mengandung keadilan, kebenaran, rahmat, dan maslahat, sebagaimana firman Allah: "Dan tiadalah kami mengutus kamu, melainkan untuk menjadi rahmat bagi semesta alam" (QS. 21:107), karena itu teks harus dijadikan sebagai standar dalam melihat kemaslahatan, dalam membedakan maslahat dari mudarat, dalam membedakan kemaslahatan ukhrawi dengan kemaslahatan duniawi, serta dalam membedakan bahaya yang besar dari bahaya yang ringan.

Ketika teks dijadikan sebagai standar penilaian kemaslahatan, maka secara otomatis kita telah berperan besar dalam menghilangkan pertentangan antara teks dan kemaslahatan, karena saat itu kita telah berinteraksi dengan kemaslahatan yang selaras dengan teks. Namun jika bersandar pada subyektifitas, dari pendapat kita sendiri, dari insting dan perasaan kita, dari arus dan trend kondisi zaman kita, dan kemudian dijadikan sebagai titik tolak kemaslahatan dan disusun berdasarkan skala prioritas di atas dengan melepaskan diri dari teks, nilai, dan maknanya, maka sudah pasti akan terjadi benturan yang hebat antara teks dengan apa yang kita anggap sebagai kemaslahatan, dan saat itu teks terpinggirkan dan kita menjadi terasing dari teks.

Terkait dengan itu, Ibnu Taimiyah mengingatkan dan mengkritik beberapa orang yang berbicara tentang kemaslahatan namun mereka melalaikannya, yaitu dengan mengatakan: "ibadah batiniyah dan jasmaniyah merupakan bentuk dari ma'rifah terhadap Allah, para malaikat, kitab-kitab, dan rasul-rasul Nya. Adapun perilaku jiwa dan aktivitasnya: seperti cinta dan takut kepada Allah, ikhlas terhadap agama, tawakkal, berharap rahmat dan karuniaNya, dan lainnya merupakan bentuk dari kemaslahatan di dunia dan akhirat. Sedangkan apa yang diperintahkanNya dari menepati janji, menyambung silaturrahmi, menghormati hak pemilik, tetangga, dan hak sebagai muslim atas muslim yang lain, dan lain-lain dari yang diperintahkan dan dilarangNya, adalah untuk memelihara kondisi sosial yang baik 
dan pemberlakuan akhlak terpuji. Bagian ini membuktikan bahwa apa yang dibawa syariah adalah kemaslahatan. ${ }^{24}$

Sebagaimana Rasulullah mengingatkan akan kehormatan hak-hak muslim dan kemaslahatannya, beliau bersabda: Setiap muslim atas muslim yang lain dilarang menumpahkan darahnya, mengambil hartanya, dan merusak kehormatannya. ${ }^{25}$ Terkadang beliau menjelaskan kemaslahatan untuk mengingatkan manusia atasnya, atau menjelaskan kehormatan dengan menggunakan perbandingan.

\section{Tafsir Kemaslahatan atas Teks}

Tafsir kemaslahatan (al-tafsir almaslahah) atas teks maksudnya adalah kajian dan analisa terhadap tujuan-tujuan teks dan kemaslahatan yang dituju dari hukum-hukumnya, kemudian melakukan interpretasi dalam menentukan makna dan kandungannya sesuai apa yang diharapkan dari kemaslahatan, dan itu tidak dengan paksaaan atau dalam tekanan. Tafsir ini bukan sekedar kajian yang bersifat formalitas atas ketetapan bahwa syariat adalah kemaslahatan dan rahmat.

Tafsir kemaslahatan atas teks telah menghilang, hal ini disebabkan adanya asumsi kontradiksi teks dan kemaslahatan. Pada dasarnya pertentangan yang terjadi adalah antara kemaslahatan dan pemahaman kaku dan sempit atas teks. Ketika teks ditafsirkan dengan tafsiran yang hilang tujuan dan nilai kemaslahatan atau dengan yang lain. Misalnya dalam ibadah, ketika dipahami tujuannya, dimensi spiritualitasnya, pengaruh pada pendidikan dan kejiwaan, dan manfaat sosialnya, maka ketentuan hukumnya menjadi sesuatu yang nikmat dan mengasikkan, menjadi panutan bagi pencari kebenaran dan menjadi landasan bagi para pendidik dan reformis. Namun jika ibadah dianggap sebagai beban yang memberatkan dan upacara seremonial belaka, maka agama diberlakukan sesuai dengan

\footnotetext{
${ }^{24}$ Ibnu Taymiyah, Majmu' al-Fatâwa, Vol. 32, (Rabat: Maktabah Ma'arif, t,t ), 234.

${ }^{25}$ Sahih Muslim, Kitab al-Birr Wa al-Silah wa al-Adab.
}

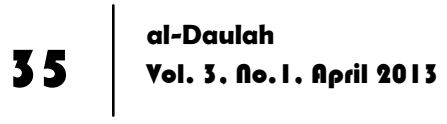


kebutuhannya atas waktu, usaha dan harta. Begitulah, ibadah dalam konteks ini dianggap mengganggu kemaslahatan dan bertentangan dengan diri manusia. Orang-orang yang memahami agama seperti ini, melakukan ibadah hanya untuk melepaskan beban atau malah meninggalkannya demi kepentingan yang lain.

Di kalangan fuqaha telah dikenal paham pemikiran yang menganggap ketentuan hukum ibadah adalah pembebanan dan keharusan, oleh karena itu wajib dilakukan secara disiplin dan literal pelaksanaan hak-hak Tuhan tersebut sebagai pelepasan dari tanggungjawab. Mereka berlebihan dan menganggap berat apa yang dibebankan Ruh dan tujuan-tujuan ibadah yang memandang ibadah sebagai keringanan, rahmat, kebaikan, dan kemudahan dikesampingkan. Bahkan terhadap rukhsah (keringanan dalam ibadah) yang ditetapkan teks, dianggap terlalu sulit syaratsyaratnya. Syekh Abdul Hayyi ibn al-Siddiq telah menulis sebuah buku yang lengkap sebagai penolakan atas fikih yang dianggap sulitd dan berat, khususnya dalam bab taharah (bersuci) dan salat. Disebutkan bahwa rukhsah yang merupakan keringanan dan kemudahan pada dasarnya adalah pembebanan dan pemberatan, karena rukhsah yang disyariahkan Allah bagi hamba-Nya untuk memudahkan dan menghilangkan kesulitan, ternyata lebih berat praktek pelaksanaannya daripada perbuatan yang disyariahkan sejak awal. ${ }^{26}$

\section{Aktualisasi Kemaslahatan atas Teks}

Aktualisasi kemaslahatan (al-tatbiq al-maslahi) atas teks adalah cabang dan perluasan dari tafsir kemaslahatan (al-tafsir al-maslahi) atas teks. Aktualisasi ini berperan dalam menghilangkan kondisi yang dipandang menimbulkan kontradiksi antara teks dan kemaslahatan. Yakni dengan aktualisasi kemaslahatan atas teks, mengikuti tujuan-tujuan teks dan kemaslahatan yang dituju dalam proses aktualisasi tersebut. Ini adalah upaya kompromistik dalam

${ }^{26}$ Abdul al-Hay al-Siddiq, Rakhsu al-Taharah wa al-Salat wa Tashdidat al-Fuqaha', (Matabi' Bughaz Tanzah, I $413 \mathrm{H} / 1992 \mathrm{H})$. 
membumikan teks, dan mengakomodasi kondisi yang sesuai dengan makna teks dan yang tidak sesuai, serta kondisi yang ditengarai sebagai pengecualian yang bersifat permanen atau bersifat penentangan.

Perlu diketahui, bahwa aktualisasi kemaslahatan (al-tatbiq almaslahiy) ini banyak ditemukan dalam khazanah intelektual klasik kita khususnya dalam kitab-kitab fikih dan usul fikih (teori dan prinsip-prinsip yurisprudensi) dengan mengambil bentuk dan istilah yang bermacam-macam, namun substansinya adalah aktualisasi teks dan hukum syariah menuju tercapainya kemaslahatan dan mencegah kemudaratan semaksimal mungkin.

Landasan dan titik tolak ini semua adalah metode Nabi Muhammad dan para sahabatnya. Salah satu contohnya adalah hadits Abu Musa r.a, ia berkata: saya menemui Rasulullah dan saya bersama dua orang laki-laki dari kabilah paman saya. Salah satu dari keduanya berkata: "wahai Rasulullah jadikanlah kami pemimpin atas sebagian kekuasaan yang telah Allah berikan kepadamu, dan yang lain pun berkata demikian. 'Rasul bersabda: Sesungguhnya demi Allah tidak akan kami berikan kepemimpinan atas pekerjaan ini pada orang yang memintanya dan juga orang berusaha memilikinya".27

Hadis ini jelas dan dipertegas dengan sumpah, bahwa siapapun yang meminta kedudukan dan kekuasaan atau yang berusaha mencapainya, maka jangan diberikan. Tujuan dan kemaslahatannya sangat jelas dan tidak disembunyikan. Tidak dapat dipungkiri bahwa persoalan utamanya sejak dahulu sampai sekarang adalah pertentangan perebutan kekuasaan antara mereka yang menginginkannya, dan kemudian berkuasa atas umat tanpa kecakapan dan keahlian atau persetujuan mereka. Hadis ini memberi pelajaran akan penyakit tamak pada jiwa yang tercermin pada kecintaan akan kekuasaan, pemujaan dan sanjungan yang ujung-ujungnya adalah pemenuhan materi dan kepuasan pribadi.

27 Sahih Muslim, Kitab al-Imarah. 
Oleh karena itu semua, maka perlu aktualisasi kemaslahatan yang tercerahkan dengan melihat, mempertimbangkan, dan mengecualikan kondisi yang mengarah pada kerusakan, sehingga tercipta kemaslahatan lain yang lebih jelas. Sebagaimana dicontohkan Nabi Muhammad ketika memberikan kekuasaan dan kepemimpinan kepada yang memintanya, hal ini terjadi pada kisah Ziyad ibn Harits dan kabilah Suda', Ziyad adalah orang yang memimpin urusan kabilahnya ketika menemui Nabi untuk menyatakan keislaman mereka yang kemudian keislaman tersebut diikuti oleh kaumnya. Ziyad berkata: "saya meminta kepada beliau (Rasulullah) untuk menunjuk saya menjadi pemimpin atas kaumku, dan Beliau memerintahkan saya hal sedemikian, maka saya laksanakan." 28

Ibnu Qayyim mengomentari kisah ini dengan mengatakan: "boleh menunjuk seorang pemimpin dan memberinya kekuasaan jika dianggap mumpuni dan mampu". Mengapa permintaanya tidak menjadi larangan atas kepemimpinannya, dan apakah tidak bertentangan dengan pernyataan hadits lain: "Sesungguhnya saya tidak akan memberikan kepemimpinan atas pekerjaan kami kepada orang yang menginginkannya". Jika diperhatikan ternyata Ziyad ibn Harits meminta kepemimpinan khusus atas kaumnya, karena dia ditaati dan dicintai kaumnya.

Maksud kedatangannya adalah untuk memperbaiki kaumnya dan menyerukan Islam kepada mereka. Nabi melihat bahwa kemaslahatan kaumnya terletak pada kepemimpinannya, maka beliau menerima permintaanya. Sedangkan pada hadits pertama, sang peminta mengharapkan kekuasaan demi kepentingan pribadinya, maka Nabi menolaknya. Beliau memberikan kekuasaan demi kemaslahatan, begitu pula sebaliknya menolak memberikan kekuasaan demi kemaslahatan. Dan pemberian

${ }^{28}$ Ibn al-Qayyim, Abdurrahman bin Abil Hasan Ali bin Muhammad bin al-Qayyim al-Jauziyyah, Zad al-Ma'ad, Juz III, (Muassasah al-Risalah wa Maktabah al-Manar sl-Islamiyah, I410 H/I990 M), 668 . 
kekuasaan pada diri Nabi adalah karena Allah, begitu pula penolakannya juga karena Allah semata. ${ }^{29}$

Banyak contoh lain dalam hadis Nabi yang memerintahkan umat Islam untuk mentaati pemimpin meskipun ia adalah budak dari Etiopia, ketaatan dalam suka dan duka, apalagi dalam tugastugas kemiliteran. Disebutkan dalam hadis sahih dari Ali r.a, bahwa Rasulullah mengirim pasukan dan menunjuk salah seorang menjadi pemimpin. Maka terjadilah keributan. Dikatakan: masuklah ke dalamnya, maka orang-orang berusaha mengikutinya. Dan yang lain mengatakan: kami telah meninggalkannya. Kemudian hal ini dilaporkan ke Rasulullah dan beliau bersabda kepada orang-orang yang masuk di dalamnya, jika kamu mengikutinya maka kamu tetap bersamanya sampai hari kiamat, dan mengatakan kepada yang lain dengan perkataan yang baik. ${ }^{30}$ Sikap Nabi dalam peristiwa ini adalah mengingatkan dan mencela bagi siapa yang memahami teks secara kaku, tidak peduli akan kebaikan dan keburukan, dan tidak memahami tujuan dan kemaslahatan. Sedangkan pujian yang Nabi berikan bagi mereka yang mengaktualisasikan teks secara sadar dan tercerahkan.

Contoh lainnya adalah apa yang diriwayatkan Ibn Qayyim dari gurunya Ibn Taimiyyah, ia berkata: "pada masa pendudukan tartar, saya bersama beberapa kawan bertemu dengan sekelompok orang yang minum khamr (minuman yang memabukkan). Salah seorang diantara kami mencela mereka, dan saya pun menegur orang yang mencela itu, lalu saya katakan: "sesungguhnya Allah mengharamkan khamr karena menghalangi kita dari dzikir dan shalat. Sedangkan bagi mereka khamr menghalangi mereka untuk membunuh, menculik dan merampok, maka biarkanlah." 31

\footnotetext{
${ }^{29} \mathrm{lbid}$.

${ }^{30}$ Sahih Muslim, Kitab al-Imarah.

${ }^{31}$ Ibn al-Qayyim, A'lam al-Muwaqqiïn, vol. 3, (Beirut: Dar Al-Jail, t,t), 5.
} 


\section{Penutup}

Kemaslahatan adalah ruh penting di balik syariah, tetapi mengambilnya dari setiap proses ijtihad bukanlah sesuatu yang bisa dilakukan oleh sembarang orang dan tanpa dasar pijakan yang kokoh dari teks suci al-Qur'an dan hadis. Konklusi dari pembahasan ini adalah bahwa munculnya kontradiksi kemaslahatan dan teks, pada dasarnya tidak lain dari dua hal: pertama, kesalahan dalam memahami dan menyimpulkan kemaslahatan, kedua, kesalahan dalam memahami dan mengaktualisasikan teks.

\section{Daftar Pustaka}

Ghozali (al-), Imam. Al-Mankhul Min Ta'liqot al-Ushul. Damaskus: Darul Fikr, 1980, Cet: II.

Jauziyyah (al-), Ibn al-Qayyim. Zâd al-Ma'âd. Beirut: Muassasah alRisalah wa Maktabah al-Manar sl-Islamiyah, 1410 H/1990 M, jilid III

Jum'ah, Ali. Qadiyyah Tajdid, Usul al-Fiqh. Beirut: Dar al-Hidayah, 1414/1993.

Juwayni (al-), Abu al-Ma'ali 'Abd al-Malik. Kitab al-Ijtihad min Kitab al-Talkhis. Damascus: Dar al-Qalam, 1987.

Khalaf, Abdul Wahab. Masadir at-Tasyri' al-Islami fima la Nas Fihi, Kuwait: Dar al-Qalam, 1392 H / 1972 M, Cet. III.

Mahmasani, Subhi. Falsafah al-Tashri' fi al-Islam. Beirut: Dar al'Ilm li-Malayin, 1961.

Naifur (al-), Muhammad al-Syazili. Man bahasa lahu 'an al-Maslahah al-Mursalah, dalam Multaqa al-Imam Muhammad ibn Arafah. Mansyurat al-Hayat al-Tunisiyah, 1977.

Qarafi (al-), al-Din Ahmad bin Idris. Al-Zakhirah, Bayrut: Dar alGharb al-Islami, 1994.

Qardawi, Yusuf. Ijtihad al-Muasir baina al-Indibat wa al-Infirat. Dar al-Tauzi' wa al_Nasyr al-Islamiyah, 1994-1414. 
Qayyim (al-), Ibn. A'lâm al-Muwaqqi'in. Beirut: Dar Al-Jail, t,t., vol 3 h.5. Talbis Iblis.

Rushd, Ibn. Bidayah al-Mujtahid, 2/154, Damaskus: Dar Fikr, Damaskus, 1980.

Sa'labi (al-), Muhammad al-Hajawi. al-Fikr al-Sami fi tarikh al-figh alIslami, vol. 2

Sahih Muslim. Kitab al-Birr Wa al-Silah wa al-Adab

-------. Kitab al-Imarah

Siddiq (al-), Abdul al-Hay. Rakhsu al-Thaharah wa al-Salat wa Tasydidat al-Fuqaha, Matabi' Bughaz Tanzah, 1413 H/1992.

Suyuti (al-), Jalal al-Din 'Abd al-Rahman. Ikhtilaf al-Madhahib, ed. 'Abd al-Qayyum Muhammad al-Bastawi. Cairo: Dar alI'tisam, $1404 \mathrm{H}$.

Syahru, Muhammad. Dirasat Islamiyah Muasirah fi ad-Daulah wa alMujtama. Damaskus: Al-Ahali li al-Taba ah wa al-Nasyr wa alTauzi', 1994.

Syahrur, Muhammad. Dirâsat Islamiyah Muâsirah fi ad-Daulah wa alMujtama, Damaskus: Al-Ahali li al-Taba ah wa al-Nasyr wa alTauzi', 1994.

Talbi, Muhammad. Iyaullah, Afkâr Jadidah fi 'Alaqah al-Muslim bi Nafsihi wa bi al-Akharin. Dar Siras li al-Nasr, 1992.

Taymiyah, Ibnu. Majmu' al-Fatawa, Vol. 32. Rabat: Maktabah Ma'arif, t,t.

Ubaidah, Abi. Al-Amwâl li Abi 'Ubaidah. Cairo: al-Maktabah atTijariyah al-Kubra, t.t. 